\title{
METABOLISM OF MUCOPOLYSACCHARIDES IN CONNECTIVE TISSUE. I. STUDIES OF ENZYMES INVOLVED IN GLUCURONIDE METABOLISM *
}

\author{
By ALFRED JAY BOLLET, $\dagger$ JESSE F. GOODWIN ANd AUDREY K. BROWN \\ (From Wayne State University College of Medicine, and Detroit Receiving Hospital, \\ Detroit, Mich.)
}

(Submitted for publication October 6, 1958; accepted October 23, 1958)

Details of the intermediary metabolism of mucopolysaccharides have been studied in microorganisms and some animal tissues (1). We have undertaken an exploration of enzymatic steps in the synthesis of mucopolysaccharides in extracts of the connective tissue which enter polyvinyl sponges inserted under the skin of guinea pigs and extracts of human synovial tissue obtained surgically.

Uridine diphosphoglucuronic acid (UDPGA) is presumed to be the donor of glucuronic acid in the synthesis of acid mucopolysaccharides (1). This report concerns primarily the enzymatic steps involved in the synthesis of UDPGA from glucose, and other enzymes involved in the metabolism of glucuronides, including glucuronosyl transferase and beta-glucuronidase. Schematic outline of the actions of the enzymes studied is given in Table I.

\section{METHODS}

Polyvinyl (Ivalon ${ }^{\circledR}$ ) sponges were inserted under the dorsal skin of male guinea pigs, weighing $500 \pm 100 \mathrm{Gm}$., anesthetized with pentobarbital $(20 \mathrm{mg}$. per $\mathrm{Kg}$.). The animals were fed standard Purina guinea pig chow. After two to four weeks, they were killed by a blow on the head, and the sponges and liver were removed and homogenized separately. Synovial tissue was obtained from human beings at the time of arthrotomy for orthopedic surgery or on removal of ganglia. All steps were carried out at 0 to $4^{\circ} \mathrm{C}$. Activities are expressed per milligram of protein, except where indicated.

1. Hexokinase a) Preparation. The 0 to 50 per cent ammonium sulfate fraction from particle free supernatant was prepared following the procedure described by Crane and Sols (2) for liver hexokinase.

b) Assay. Aliquots of the enzyme preparations were assayed by two methods. After incubation under the

* Supported by grants from the Michigan Chapter of The Arthritis and Rheumatism Foundation; the Receiving Hospital Research Corporation; and the National Institutes of Health, United States Public Health Service (Grant RG-5105).

$\dagger$ John and Mary R. Markle Scholar in Medical Science. conditions specified by Crane and Sols (2), the change in acid-labile phosphorus was determined following hydrolysis in $5 \mathrm{~N} \mathrm{H}_{2} \mathrm{SO}_{4}$ for five minutes at $100^{\circ}$. Phosphorus determinations were done by the method of Goodwin (3). As a second method of assay, the entire incubation mixture was added to a solution containing $0.6 \mathrm{mM}$ of glycylglycine buffer, $\mathrm{pH} 7.4,0.2 \mu \mathrm{M}$ of triphosphopyridine nucleotide $(\mathrm{TPN}), 0.01 \mathrm{mM}$ of $\mathrm{MgCl}_{2}$ and 0.0015 unit of glucose-6-phosphate dehydrogenase (Sigma, Type III) in a total volume of $1.9 \mathrm{ml}$. The subsequent reduction of TPN to TPNH was read at $340 \mathrm{~m} \mu$ in a Beckman DU spectrophotometer. In both procedures, controls consisted of the same incubation mixture heatinactivated at zero time, and incubation carried out with glucose omitted.

2. Phosphoglucomutase. a) Preparation. The initial steps in the procedure described by Najjar (4) were followed; extracts were made in four volumes of distilled water, heated to $65^{\circ} \mathrm{C}$., and a 0 to 65 per cent ammonium sulfate fraction obtained. Assays were done within 30 hours of the start of the preparation.

b) Assay. The method of Najjar (4) was used; glucose-1-phosphate conversion to glucose-6-phosphate was determined by the fall in acid-labile phosphorus by the method of Goodwin (3). Controls consisted of the same systems heat-inactivated at zero time.

3. Uridine diphosphoglucose ( $U D P G$ ) pyrophosphorylase and dehydrogenase. a) Preparation. Forty to 55 per cent ammonium sulfate fraction was obtained from water extracts of the tissue, following the initial two steps in the procedure of Strominger, Maxwell, Axelrod and Kalckar (5) for the purification of UDPG dehydrogenase. This fraction was suspended in $0.02 \mathrm{M}$ acetate buffer, $\mathrm{pH} 5.4$, and dialyzed against that buffer for five hours.

b) Assay of UDPG pyrophosphorylase. One-tenth $\mu \mathrm{M}$ of uridine triphosphate, $20 \mu \mathrm{M}$ of glucose-1-phosphate, $5 \mu \mathrm{M}$ of diphosphopyridine nucleotide (DPN), $250 \mu \mathrm{M}$ glycine buffer, $\mathrm{pH} 8.7$, and 5 units of purified UDPG dehydrogenase (Sigma), in a total volume of $0.8 \mathrm{ml}$., were placed in microcuvettes; $0.1 \mathrm{ml}$. of the enzyme preparation to be tested was added. The formation of reduced diphosphopyridine nucleotide (DPNH) was determined spectrophotometrically at $340 \mathrm{~m} \mu$ in a Beckman model DU spectrophotometer at room temperature. Controls included similar systems with uridine triphosphate omitted. In this and other controls run with glucose-1-phosphate omitted or with uridine diphosphate 
TABLE I

Outline of enzymatic reactions studied in connective tissue *

\begin{tabular}{|c|c|c|}
\hline Enzyme & & Reaction \\
\hline $\begin{array}{l}\text { Hexokinase } \\
\text { Phosphoglucomutase } \\
\text { UDPG pyrophosphorylase } \\
\text { UDPG dehydrogenase } \\
\text { Glucuronosyl transferase } \\
\text { Beta-glucuronidase } \\
\text { Cytochrome c reductase }\end{array}$ & $\begin{array}{l}\text { Glucose + ATP } \\
\text { Glucose-6-PO } \\
\text { Glucose-1-PO }+ \text { UTP } \\
\text { UDPG + 2 DPN } \\
\text { R-OH + UDPGA } \\
\text { R-GA + HOH } \\
\text { DPNH + } 2 \text { Cytochrome c } \\
\quad\left(\mathrm{Fe}^{+++}\right)\end{array}$ & $\begin{array}{l}\rightarrow \text { Glucose-6-PO } \mathrm{PO}_{4}+\mathrm{ADP} \\
\rightleftharpoons \text { Glucose-1-PO } \\
\rightleftharpoons \text { UDPG }+\mathrm{PP} \\
\rightarrow \text { UDPGA }+2 \mathrm{DPNH}+2 \mathrm{H}^{+} \\
\rightarrow \text { R-GA }+\mathrm{UDP} \\
\rightarrow \text { R-OH }+\mathrm{GA} \\
\rightarrow \mathrm{DPN}^{+}+\underset{\left(\mathrm{Fe}^{++}\right)}{2 \mathrm{Cy} \text { tochrome } \mathrm{c}+\mathrm{H}^{+}}\end{array}$ \\
\hline
\end{tabular}

* Abbreviations used: ATP = adenosine triphosphate; ADP = adenosine diphosphate; UTP = uridine triphosphate; UDPG = uridine diphosphoglucose; UDPGA = uridine diphosphoglucuronic acid; PP = pyrophosphate; DPN $=$ diphosphopyridine nucleotide; DPNH = reduced diphosphopyridine nucleotide; GA = glucuronic acid.

substituted for the uridine triphosphate, very little reduction of DPN occurred. Activity was expressed as micromoles of DPN reduced per minute during the second to sixth minutes of incubation, correcting for any DPN reduction in controls run simultaneously.

c) Assay of UDPG dehydrogenase. The formation of DPNH was determined spectrophotometrically, following the procedure of Strominger, Maxwell, Axelrod and Kalckar (5). Controls consisted of the same incubation mixture with UDPG omitted. Activity was expressed in the same manner as was used for UDPG pyrophosphorylase.

5. Glucuronosyl transferase. a) Preparation. Homogenates were made in $0.25 \mathrm{M}$ sucrose buffered to $\mathrm{pH}$ 7.6. For some experiments, the sediment obtained by ultracentrifugation between 37,000 and $80,000 \times G$ was used, suspended in $0.25 \mathrm{M}$ sucrose.

b) Assay using o-aminophenol as acceptor. The sediment obtained by ultracentrifugation was incubated with $0.2 \mu \mathrm{M}$ of UDPGA (Sigma), $0.1 \mathrm{mM}$ of $\mathrm{MgCl}_{2}, 0.55 \mu \mathrm{M}$ of recrystallized $o$-aminophenol and $0.035 \mathrm{mM}$ tris(hy-

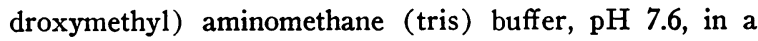
total volume of $1.0 \mathrm{ml}$. After incubation at $37^{\circ} \mathrm{C}$. for 45 minutes, $o$-aminophenol glucosiduronic acid formation was determined by the method of Levvy and Storey (6).

c) Assay using 4-methyl umbelliferone as acceptor. ${ }^{1}$ Homogenate in sucrose was incubated for 15 minutes at $37^{\circ} \mathrm{C}$. with $0.2 \mu \mathrm{M}$ of UDPGA, $0.1 \mathrm{Gm}$. of $\mathrm{MgCl}_{2}, 0.35$
$\mathrm{mM}$ of tris buffer and $0.2 \mu \mathrm{M}$ of 4-methyl umbelliferone in a total volume of $2.2 \mathrm{ml}$. The incubation mixture was then shaken with $10 \mathrm{ml}$. of chloroform twice to denature protein and extract unconjugated umbelliferone. Aliquots of $0.5 \mathrm{ml}$. of the incubation mixture were then incubated

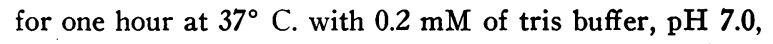
and 50 units of bacterial beta-glucuronidase (Sigma) in a total volume of $2.0 \mathrm{ml}$. Five $\mathrm{ml}$. of glycine buffer, $0.5 \mathrm{M}, \mathrm{pH} 10.35$, was then added and fluorescence determined and compared to the fluorescence of similar aliquots carried through the same procedure without betaglucuronidase. The increase in fluorescence following incubation with beta-glucuronidase was considered to indicate the amount of umbelliferone which was conjugated with glucuronic acid in the initial incubation.

6. Beta-glucuronidase. a) Preparation. Assays were done using homogenate suspended in $0.25 \mathrm{M}$ sucrose buffered to $\mathrm{pH} 7.6$.

b) Assay. The procedure of Fishman and Bernfeld (7) was followed. Results are expressed as micrograms

1 The assay procedure used was based on suggestions of Dr. Gordon Tompkins of the National Institute of Arthritis and Metabolic Diseases, Bethesda, Md. This method was found to give results proportional to the amount of protein in the incubation mixture only when small amounts of enzyme activity were present. Liver homogenates were diluted so that only one mg. of protein, or less, was used in the assay.

TABLE II

Clinical data on human synovial tissue samples studied

\begin{tabular}{|c|c|c|c|c|}
\hline $\begin{array}{l}\text { Tissue } \\
\text { sample }\end{array}$ & Source & Diagnosis & Sex & Age \\
\hline A & Hip & $\begin{array}{l}\text { Osteoarthritis secondary to aseptic necro- } \\
\text { sis of femoral head }\end{array}$ & $\mathbf{M}$ & 38 \\
\hline B & Knee & Charcot joint & $\mathbf{F}$ & 39 \\
\hline $\mathrm{C}$ & Knee & Torn meniscus & M & 24 \\
\hline $\mathrm{D}$ & Tendon sheath & Ganglion & $\mathbf{F}$ & 33 \\
\hline $\mathrm{E}$ & Tendon sheath & Ganglion (pooled tissue from 2 patients) & & \\
\hline $\mathrm{F}$ & Knee & Fracture of patella & $\mathbf{F}$ & 57 \\
\hline $\mathrm{G}$ & Hip & Rheumatoid arthritis & $\mathbf{M}$ & 32 \\
\hline $\mathrm{H}$ & Knee & Rheumatoid arthritis & $\mathbf{M}$ & 50 \\
\hline
\end{tabular}


TABLE III

UDPG pyrophosphorylase and UDPG dehydrogenase activity of 40 to 55 per cent ammonium sulfate fraction obtained from extracts of guinea pig tissue and human synovial tissue*

\begin{tabular}{|c|c|c|c|c|c|c|}
\hline \multirow[b]{2}{*}{ Tissue sample } & \multicolumn{3}{|c|}{ UDPG pyrophosphorylase } & \multicolumn{3}{|c|}{ UDPG dehydrogenase } \\
\hline & Mean & S.E.M.† & $\begin{array}{l}\text { No. of } \\
\text { observa- } \\
\text { tions }\end{array}$ & Mean & S.E.M.† & $\begin{array}{l}\text { No. of } \\
\text { observa- } \\
\text { tions }\end{array}$ \\
\hline \multicolumn{7}{|l|}{ A. Guinea pig tissues } \\
\hline $\begin{array}{l}\text { Sponge tissue } \\
\text { Liver }\end{array}$ & $\begin{array}{l}0.5 \\
3.0\end{array}$ & $\begin{array}{l} \pm 0.18 \\
\pm 0.41\end{array}$ & $\begin{array}{r}10 \\
8\end{array}$ & $\begin{array}{r}1.5 \\
13.9\end{array}$ & $\begin{array}{l} \pm 0.18 \\
\pm 1.30\end{array}$ & $\begin{array}{l}13 \\
10\end{array}$ \\
\hline \multicolumn{7}{|c|}{ B. Human synovial tissues } \\
\hline $\begin{array}{l}\mathrm{A} \\
\mathrm{B} \\
\mathrm{H}\end{array}$ & $\begin{array}{l}0.2 \\
0.02 \\
0.8\end{array}$ & & & $\begin{array}{l}0.3 \\
0.5 \\
0.7\end{array}$ & & \\
\hline
\end{tabular}

* Figures given are micromoles $\left(\times 10^{-3}\right)$ of diphosphopyridine nucleotide reduced per minute per mg. of protein. + S.E.M. = standard error of the mean.

of phenolphthalein released from phenolphthalein glucuronide after one hour at $37^{\circ} \mathrm{C}$.

7. Cytochrome c reductase. a) Preparation. Assays were done on homogenate suspended in $0.25 \mathrm{M}$ sucrose buffered to $\mathrm{pH}$ 7.6.

b) Assay. The method described by Mahler (8) was used; 2,6-dichlorphenol indophenol was used as the electron acceptor. The incubation mixture consisted of 1.3 $\mathrm{ml}$. of $0.05 \mathrm{M}$ phosphate buffer, $\mathrm{pH} 7.4$, containing 0.001 $\mathrm{M} \mathrm{KCN}, 0.18 \mu \mathrm{M}$ of dye, $0.6 \mu \mathrm{M}$ of DPNH, and homogenate in a total volume of $2.6 \mathrm{ml}$. Dye reduction was determined in a Beckman DU spectrophotometer at 600 $\mathrm{m} \mu$ at room temperature. Results are reported as micromoles of dye reduced between the thirtieth and one hundred twentieth seconds of incubation.

8. Protein determination. Protein in the samples assayed was estimated by the determination of ultraviolet absorption at 280 and $260 \mathrm{~m} \mu$, as described by Layne (9).

\section{RESULTS}

The figures given for guinea pig tissues are mean values, while the figures given for human synovial tissues are individual determinations; clinical data for these cases are given in Table II.

Hexokinase. The fraction prepared from sponge granulomas was found to have hexokinase activity, demonstrated by the transfer of acid-labile phosphorus of adenosine triphosphate (ATP) to acidstable phosphorus of glucose-6-phosphate. In the assay procedure used, $80 \mu \mathrm{M}$ of ATP was converted per gram of sponge tissue extracted.

Phosphoglucomutase. Sponge tissue converted an average of $64 \times 10^{-2} \mu \mathrm{M}$ of glucose-1-phosphate to glucose-6-phosphate per gram of tissue extracted, under the conditions used.

$U D P G$ pyrophosphorylase and UDPG dehy- drogenase. The active fractions obtained from sponge tissues were found to have 17 per cent of the UDPG pyrophosphorylase, and 11 per cent of the UDPG dehydrogenase activity of similar fractions isolated from the livers of the same animals (Table III). Following incubation, the mixtures used in the assay of the UDPG pyrophosphorylase and dehydrogenase from sponge and liver tissue were adjusted to $\mathrm{pH} 3.1$, and adsorbed with charcoal (Norit A). The charcoal was eluted with ethanol containing 1:1,000 ammonium hydroxide, and a carbazole procedure was run on the eluates according to the method of Dische (10) to demonstrate the formation of glucuronic acid. A pink color with an absorption spectrum corresponding to that of glucuronolactone was found in each instance.

Activity of these enzymes was also demonstrated in human synovial tissue (Table III).

TABLE IV

Glucuronosyl transferase activity of guinea pig tissue and human synovial tissue, using 4-methyl umbelliferone as acceptor

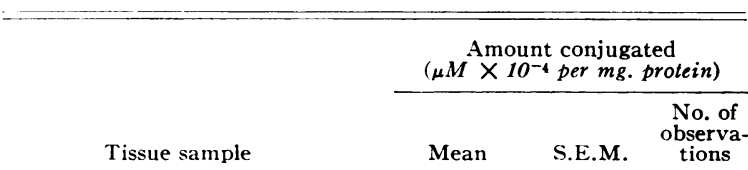

A. Guinea pig tissues Sponge tissue

$\begin{array}{rlr}2.3 & \pm 0.54 & 8 \\ 110.0 & +7.7 & 8\end{array}$

B. Human synovial tissues
0.5 
TABLE $\mathrm{V}$

Beta-glucuronidase activity of human synovial tissue

\begin{tabular}{cc}
\hline $\begin{array}{c}\text { Tissue } \\
\text { sample }\end{array}$ & $\begin{array}{c}\mu \mathrm{g} . \text { of phenolphthalein } \\
\text { released per mg. } \\
\text { of protein }\end{array}$ \\
\hline A & 10.2 \\
B & 12.1 \\
C & 11.0 \\
F & 9.0 \\
G & 12.5 \\
H & 15.8 \\
\end{tabular}

Glucuronosyl transferase. Conjugation of $o$-aminophenol to $o$-aminophenol glucosiduronic acid took place when the ultracentrifugational sediment obtained from sponge tissue extracts was used as the source of glucuronosyl transferase; $9.6 \times 10^{-3} \mu \mathrm{M}$ of substrate was conjugated per gram of sponge tissue. This activity was 7 per cent of the activity of the same fraction isolated from the liver. Using crude homogenates of sponge extracts and 4-methyl umbelliferone as the acceptor, glucuronosyl transferase activity was again demonstrable. With this system the sponge tissue was found to have 2.1 per cent of the activity of liver homogenates and this enzyme was also found in homogenates of human synovial tissue (Table IV).

Beta-glucuronidase. Sponge tissue homogenates were found to release an average $18.6 \mu \mathrm{g}$. (standard error \pm 2.6 ) of phenolphthalein per $\mathrm{mg}$. of protein; homogenates of the liver of the same 10 animals released an average of $11.9 \pm 1.1 \mu \mathrm{g}$. of phenolphthalein per $\mathrm{mg}$. of protein. Synovial tissue homogenates also had beta-glucuronidase activity (Table V).

\section{DISCUSSION}

The intermediary metabolism of the mucopolysaccharides of connective tissue has been studied in a variety of microorganisms and some vertebrate tissues, but has not been studied previously in mammalian connective tissue. Granulation tissue proliferation can be induced in experimental animals by the insertion of polyvinyl sponges (11). Fibroblasts, small vessels and a few giant cells appear in these sponges without inflammatory cell infiltration; the mucopolysaccharide concentration in the sponges reaches a peak at two weeks (12). This tissue provides a means of investigation of mucopolysaccharide metabolism in mammalian connective tissue.

The finding in connective tissue of the enzymes necessary to synthesize UDPGA from glucose supports the likelihood that UDPGA is an intermediary in the synthesis of the glucuronic acid moiety of mucopolysaccharides. This possibility has been suggested by the observation of Glaser and Brown (13) that labeled UDPGA is incorporated into hyaluronic acid by the Rous chicken sarcoma.

The relatively high concentration of beta-glucuronidase in the sponge tissue is of interest in view of observation by Linker, Meyer and Weissmann (14) that this enzyme hydrolyzes glucuronidic bonds in oligosaccharides derived from hyaluronic acid. Since hepatic glucuronosyl transferase is considered the enzyme involved in the synthesis of glucuronides of a variety of phenolic, alcoholic and steroid compounds, with UDPGA serving as the donor of glucuronic acid (15), the presence of this enzyme in connective tissue leads to speculation concerning its biologic role in that tissue. Fishman and Green (16) have suggested that beta-glucuronidase can serve to transfer glucuronic acid from preformed glucuronides to a variety of acceptors. If this mechanism is operative in vivo, the glucuronosyl transferase might form glucuronides which serve as substrate for this reaction. These considerations, however, only serve to underscore the lack of information concerning the enzyme systems involved in the synthesis of oligosaccharides and the need for further investigation.

Cytochrome c reductase was measured as an index of general metabolic activity of the tissues

TABLE VI

Cytochrome c reductase activity of guinea pig tissue and human synovial tissue

\begin{tabular}{lccc}
\hline & & $\mu M$ dye reduced per mg. protein \\
\cline { 2 - 4 } Tissue sample & Mean & S.E.M. & $\begin{array}{c}\text { No. of } \\
\text { observa- } \\
\text { tions }\end{array}$ \\
\hline A. Guinea pig tissues & & & \\
$\quad$ Sponge tissue & 1.7 & \pm 0.55 & 4 \\
$\quad$ Liver & 7.0 & \pm 0.67 & 5 \\
B. Human synovial tissues & & & \\
B & 0.7 & & \\
G & 1.1 & & \\
H & 1.1 & & \\
& &
\end{tabular}


studied, to serve as a basis for comparison of the activity of enzymes involved in other metabolic functions. Such an index may be particularly useful in studies of connective tissue enzymes, where the relatively large amount of extracellular protein dilutes intracellular enzymes in tissue homogenates (Table VI).

Synovial tissue slices have been shown to be capable of the synthesis of mucopolysaccharide from glucose (17). The present study demonstrates activity of individual enzymes involved in mucopolysaccharide metabolism in extracts of human synovial tissue. The presence of measurable activity of these enzymes permits investigation of connective tissue metabolism in various diseases and exploration of mechanisms of action of therapeutic agents.

\section{SUMMARY}

Activity of enzymes involved in mucopolysaccharide metabolism can be demonstrated in extracts of connective tissue grown in polyvinyl sponges inserted under the dorsal skin of guinea pigs and in extracts of human synovial tissue. Enzymes involved in the synthesis of uridine diphosphoglucuronic acid (UDPGA) from glucose were studied. as were glucuronosyl transferase, beta-glucuronidase and cytochrome $\mathrm{c}$ reductase. The techniques used permit comparison of mucopolysaccharide metabolism in synovial tissue in various clinical states.

\section{ACKNOWLEDGMENTS}

The authors would like to express their thanks to IVilliam F. Simpson, Douglas V. Anderson and Margaret A. Seipke for expert technical assistance.

\section{REFERENCES}

1. Whistler, R. L., and Olson, E. J. The biosynthesis of hyaluronic acid in Advances in Carbohydrate Chemistry. New York, Academic Press Inc., 1957, vol. 12, p. 299.

2. Crane, R. K., and Sols, A. Animal tissue hexokinases in Methods in Enzymology, S. P. Colowick and N. D. Kaplan, Eds. New York, Academic Press, Inc., 1955, vol. I, p. 277.
3. Goodwin, J. F. A modified chloric acid method for the determination of serum total and phospholipid phosphorus. Proc. Soc. exp. Biol. (N. Y.) Ir. press.

4. Najjar, V. A. Phosphoglucomutase from muscle in Methods in Enzymology, S. P. Colowick and N. D. Kaplan, Eds. New York, Academic Press, Inc., 1955, vol. I, p. 294.

5. Strominger, J. L., Maxwell, E. S., Axelrod, J., and Kalckar, H. M. Enzymatic formation of uridine diphosphoglucuronic acid. J. biol. Chem. 1957 224, 79.

6. Levvy, G. A., and Storey, I. D. E. The measurement of glucuronide synthesis by tissue preparations. Biochem. J. 1949, 44, 295.

7. Fishman, W. H., and Bernfeld, P. Glucuronidases in Methods in Enzymology, S. P. Colowick and N. D. Kaplan, Eds. New York, Academic Press, Inc., 1955, vol. I, p. 262.

8. Mahler, H. R. DPNH cytochrome c reductase (animal) in Methods in Enzymology, S. P. Colowick and N. D. Kaplan, Eds. New York, Academic Press, Inc. 1955, vol. II, p. 688.

9. Layne, E. Spectrophotometric and turbidimetric methods for measuring proteins in Methods in Enzymology, S. P. Colowick and N. D. Kaplan, Eds. New York, Academic Press, Inc., 1955, vol. III, p. 447.

10. Dische, Z. A new specific color reaction of hexuronic acids. J. biol. Chem. 1947, 167, 189.

11. Boucek, R. J., and Noble, N. L. Connective tissue; a technique for its isolation and study. Arch. Path. (Chicago) 1955, 59, 553.

12. Bollet, A. J., Goodwin, J. F., Simpson, W. F., and Anderson, D. V. Mucopolysaccharide, protein and desoxyribosenucleic acid concentration of granulation tissue induced by polyvinyl sponges. Proc. Soc. exp. Biol. (N. Y.) 1958, 99, 418.

13. Glaser, L., and Brown, D. H. The enzymatic synthesis in vitro of hyaluronic acid. Proc. nat. Acad. Sci. (Wash.) 1955, 41, 253.

14. Linker, A., Meyer, K., and Weissmann, B. Enzymatic formation of monosaccharides from hyaluronate. J. biol. Chem. 1955, 213, 237.

15. Kalckar, H. M., and Maxwell, E. S. Biosynthesis and metabolic function of uridine diphosphoglucose in mammalian organisms and its relevance to certain inborn errors. Physiol. Rev. 1958, 38, 77.

16. Fishman, W. H., and Green, S. Enzymatic catalysis of glucuronyl transfer. J. biol. Chem. 1957, 225, 435.

17. Yielding, K. L., Tompkins, G. M., and Bunim, J. J. Synthesis of hyaluronic acid by human synovial tissue slices. Science 1957, 125, 1300. 